\title{
Validation of an analytical method using HPLC-MS/MS to quantify osimertinib in human plasma and supplementary stability results
}

Citation for published version (APA):

van Veelen, A., van Geel, R., de Beer, Y., Dingemans, A-M., Stolk, L., Ter Heine, R., de Vries, F., \& Croes, S. (2020). Validation of an analytical method using HPLC-MS/MS to quantify osimertinib in human plasma and supplementary stability results. Biomedical Chromatography, 34(4), [e4771]. https://doi.org/10.1002/bmc.4771

Document status and date:

Published: 01/04/2020

DOI:

10.1002/bmc.4771

Document Version:

Publisher's PDF, also known as Version of record

Document license:

Taverne

Please check the document version of this publication:

- A submitted manuscript is the version of the article upon submission and before peer-review. There can be important differences between the submitted version and the official published version of record.

People interested in the research are advised to contact the author for the final version of the publication, or visit the DOI to the publisher's website.

- The final author version and the galley proof are versions of the publication after peer review.

- The final published version features the final layout of the paper including the volume, issue and page numbers.

Link to publication

\footnotetext{
General rights rights.

- You may freely distribute the URL identifying the publication in the public portal. please follow below link for the End User Agreement:

www.umlib.nl/taverne-license

Take down policy

If you believe that this document breaches copyright please contact us at:

repository@maastrichtuniversity.nl

providing details and we will investigate your claim.
}

Copyright and moral rights for the publications made accessible in the public portal are retained by the authors and/or other copyright owners and it is a condition of accessing publications that users recognise and abide by the legal requirements associated with these

- Users may download and print one copy of any publication from the public portal for the purpose of private study or research.

- You may not further distribute the material or use it for any profit-making activity or commercial gain

If the publication is distributed under the terms of Article 25fa of the Dutch Copyright Act, indicated by the "Taverne" license above, 


\title{
Validation of an analytical method using HPLC-MS/MS to quantify osimertinib in human plasma and supplementary stability results
}

\author{
Ard van Veelen ${ }^{1,2,3}$ (i) | Robin van Geel ${ }^{1,2}$ | Yvo de Beer ${ }^{1}$ | \\ Anne-Marie Dingemans $^{4}$ | Leo Stolk ${ }^{1}$ | Rob ter Heine ${ }^{5}$ | Frank de Vries ${ }^{1,3,6}$ \\ Sander Croes ${ }^{1,2}$
}

\author{
${ }^{1}$ Department of Clinical Pharmacy and \\ Toxicology, Maastricht University Medical \\ Center+, AZ, Maastricht, the Netherlands \\ ${ }^{2}$ CARIM School for Cardiovascular Disease, \\ Maastricht University Medical Center, MD, \\ Maastricht, the Netherlands \\ ${ }^{3}$ Department of Pharmacoepidemiology and \\ Clinical Pharmacology, Utrecht Institute for \\ Pharmaceutical Sciences, TB, Utrecht, the \\ Netherlands \\ ${ }^{4}$ Department of Pulmonary Diseases, GROW- \\ School for Oncology and Developmental \\ Biology, Maastricht University Medical Center, \\ Maastricht, the Netherlands \\ ${ }^{5}$ Radboud Institute for Health Sciences, \\ Department of Pharmacy, Radboud University \\ Medical Center, Nijmegen, the Netherlands \\ ${ }^{6}$ MRC Lifecourse Epidemiology Unit, \\ Southampton General Hospital, University of \\ Southampton, UK \\ Correspondence \\ Sander Croes, Maastricht University Medical \\ Centre (MUMC+), Maastricht Department of \\ Clinical Pharmacy and Toxicology PO BOX \\ 58006202 AZ Maastricht. \\ Email: s.croes@mumc.nl \\ Funding information \\ ZonMw, Grant/Award Number: \\ 80-84800-98-17042
}

\begin{abstract}
A new method for quantification of osimertinib (OSIM) in human plasma using a high-performance liquid chromatography-tandem mass spectrometry method was developed and validated. Methanol was used for protein precipitation and pazopanib as internal standard. Separation was performed on a HyPURITY ${ }^{\circledR} \mathrm{C}_{18}$ analytical column $(50 \times 2.1 \mathrm{~mm} ; 3 \mu \mathrm{m})$ using a gradient elution of ammonium acetate in water and ammonium acetate in methanol, both acidified with formic acid $0.1 \%$. Detection and quantification of OSIM and pazopanib was performed using a triple quadruple mass spectrometer after electrospray ionization. This method led to robust results, as the selectivity, carryover, precision and accuracy all met pre-specified requirements. OSIM was stable in human serum when stored at $-80^{\circ} \mathrm{C}$. Reduced stability was found when stored at $2-4^{\circ} \mathrm{C}$ or room temperature. Degradation of OSIM slowed down in EDTA-plasma and acidified human serum. The limited stability of OSIM at room temperature should be considered for transport and sample preparation. Plasma samples should be frozen as soon as possible and sample preparation should be performed on dry-ice. In the future, EDTA-plasma and sample acidification may be used to improve OSIM stability at room temperature. However, more research and validation of such an approach are required.
\end{abstract}

\section{KEYWORDS}

analysis, osimertinib, room temperature, stability, validation

\section{1 | INTRODUCTION}

Non-small cell lung cancer (NSCLC) is the most prevalent form of lung cancer (Herbst, Heymach, \& Lippman, 2008). In roughly $10 \%$ of all NSCLC patients a mutation in the epidermal growth factor receptor (EGFR) can be found (Ferlay et al., 2015). Osimertinib (OSIM) is a third-generation, irreversible, EGFR-directed tyrosine kinase inhibitor (TKI), which is registered as first- and second-line treatment in patients with EGFR-mutated NSCLC (Mok et al., 2017; Soria et al., 2018).

The pharmacokinetics of OSIM have been studied earlier (Brown et al., 2017; Planchard et al., 2016; Zhao et al., 2018). Steady-state conditions are achieved after 15 days. OSIM has a half-life between 40 and $50 \mathrm{~h}$, resulting in a relatively flat plasma concentration-time curve during steady state. OSIM, and its key metabolites AZ5104 and AZ7550, are mainly metabolized by CYP3A and substantial inter- 
patient variability in exposure is seen after multiple administration of OSIM (Planchard et al., 2016; Zhao et al., 2018).

Seven liquid chromatography-tandem mass spectrometry (LC-MS/MS) methods to quantify OSIM in human plasma have previously been reported (Irie et al., 2019; Janssen et al., 2019; Mitchell, Bailey, Ewles, Swan, \& Turpin, 2019; Reis et al., 2018; Rood, van Bussel, Schellens, Beijnen, \& Sparidans, 2016; Veerman, Lam, Mathijssen, Koolen, \& de Bruijn, 2019; Zheng et al., 2018). Four methods were single-drug methods for OSIM (and its metabolites) (Irie et al., 2019; Mitchell et al., 2019; Rood et al., 2016; Zheng et al., 2018), while two other methods focused on simultaneous determination of multiple TKIs (Janssen et al., 2019; Reis et al., 2018; Veerman et al., 2019). Short-term stability of OSIM has been evaluated in different types of plasma and in whole blood, but not one study evaluated OSIM stability in EDTA-plasma, heparinized plasma, human serum and whole blood, which makes it difficult to compare the stability results. Therefore, and for research purposes, we developed a simple high-performance liquid chromatography-tandem mass spectrometry (HPLC-MS/MS) method for the quantitative analysis of OSIM in human plasma. Herein, we describe the validation of our assay together with OSIM stability data in EDTA-plasma, sodium heparin plasma, whole blood and serum.

\section{2 | MATERIAL AND METHODS}

\subsection{Chemicals and reagents}

OSIM (free base, purity 95\%) and pazopanib (PAZO) (free base, purity 98\%) were purchased from Toronto Research Chemicals (Toronto, Ontario, Canada). Methanol (ULC/MS-CC/SFC grade) was purchased from Biosolve (Valkenswaard, the Netherlands). Acetonitrile ( $\geq 99.9 \%$ ), 2-propanol ( $\geq 99.8 \%$ ) and dimethylsulfoxide (DMSO, $\geq 99.0 \%$ ) were obtained from Merck (Darmstadt, Germany). Drug-free serum (frozen, no additives) was purchased from Sanquin (Amsterdam, the Netherlands).

\section{2 | Preparation of calibration standards and quality controls}

For the calibration standards and quality controls of OSIM, two separately prepared stock solutions (dissolved in DMSO) with a concentration of $1 \mathrm{mg} / \mathrm{ml}$ were produced. These were diluted with methanol to a concentration of $10 \mu \mathrm{g} / \mathrm{ml}$ (working solutions). The PAZO stock solution was prepared reconstituting $\sim 1 \mathrm{mg}$ PAZO with $100 \mathrm{ml}$ methanol, resulting in a concentration of $\sim 10 \mu \mathrm{g} / \mathrm{ml}$. Both OSIM and PAZO stock solutions were stored at $-80^{\circ} \mathrm{C}$ until analysis. The calibration standards consisted of six different concentrations plus a zero and a blank sample. These were prepared by spiking human serum with the working solution. The zero sample only consisted of PAZO, while the blank sample did not contain either OSIM or PAZO. Quality control
(QC) samples were prepared from the second working solution for the validation runs at five different concentrations: lowest limit of quantification (LLOQ), $25.0 \mathrm{ng} / \mathrm{ml}$; $\mathrm{QC}_{\mathrm{LOW}}, 75.0 \mathrm{ng} / \mathrm{ml}$; $\mathrm{QC}_{\text {MED }}, 250.0 \mathrm{ng} / \mathrm{ml} ; \mathrm{QC}_{\mathrm{HIGH}}, 375.0 \mathrm{ng} / \mathrm{ml}$ and upper limit of quantification (ULOQ), $500 \mathrm{ng} / \mathrm{ml}$. For study sample runs $\mathrm{QC}_{\mathrm{LOW}}$, $\mathrm{QC}_{\mathrm{MED}}$ and $\mathrm{QC}_{\mathrm{HIGH}}$ were used.

\subsection{Instrumentation}

For the analysis a Surveyor ${ }^{\circledR}$ Autosampler Plus with a quaternary MSpump plus and degasser (ThermoFischer, Breda, The Netherlands) as a chromatographic system were used. A TSQ Quantum-Access ${ }^{\circledR}$ triplequad mass spectrometer (ThermoFischer, Breda, the Netherlands) with an electrospray ionization interface combined with Excalibur ${ }^{\circledR}$ software (version 2.2SP1) was used for detection and quantification. Chromatographic separation was performed on a HyPURITY ${ }^{\circledR} \mathrm{C}_{18}$ analytical column ( $50 \times 2.1 \mathrm{~mm}, 3 \mu \mathrm{m}$, Thermo Fischer Scientific) combined with a drop-in guard (HyPURITY $\left.{ }^{\circledR} \mathrm{C}_{18}, 10 \times 2.1 \mathrm{~mm}, 3 \mu \mathrm{m}\right)$.

\section{4 | Sample preparation}

The solution for deproteinization was made by adding $2.5 \mu \mathrm{I}$ PAZO $(\sim 10 \mu \mathrm{g} / \mathrm{ml})$ to $10 \mathrm{ml}$ of methanol. A $20 \mu \mathrm{l}$ serum sample was pipetted in an eppendorf cup placed in a container filled with dry-ice. Thereafter, $150 \mu \mathrm{l}$ of deproteinization solution was added and vortexed for 2 min. After vortexing, the Eppendorf cups were centrifuged at $11,300 \mathrm{~g}$ for $5 \mathrm{~min}$. Subsequently, $100 \mu \mathrm{l}$ supernatant was pipetted in a glass vial and $400 \mu \mathrm{l}$ water was added to ensure compatibility with the gradient used during chromatography.

\subsection{Chromatographic condition and LC-MS/MS settings}

Two mobile phases were used for achieving chromatographic separation. Mobile phase A consisted of $2 \mathrm{~mm}$ ammonium acetate in water ( $+0.1 \%$ formic acid). Mobile phase B consisted of $2 \mathrm{~mm}$ ammonium acetate in methanol (+ $0.1 \%$ formic acid). The starting gradient was set at $70 \%$ A and $30 \%$ B for 0.5 min. After 0.5 min the gradient linearly increased to $100 \%$ B in 2.0 min. A concentration of $100 \%$ B was maintained for $0.3 \mathrm{~min}$ after which the gradient was reset to initial conditions and kept steady for 1 min before a new sample was injected. The flow during the run was maintained at $500 \mu \mathrm{l} / \mathrm{min}$. Column temperature was set at $60^{\circ} \mathrm{C}$. Autosampler temperature was set at $10^{\circ} \mathrm{C}$. The divert valve was set in the waste position for the first $1.5 \mathrm{~min}$.

MS detection was in multiple reaction monitoring mode with the following settings: spray voltage, $5000 \mathrm{~V}$; sheath gas pressure, 60; auxiliary gas pressure, 15 ; capillary temperature, $360^{\circ} \mathrm{C}$; collision gas pressure, 1.5 mTorr. Transition of OSIM and PAZO was set at $\mathrm{m} / \mathrm{z}$ $500.3 \rightarrow 72.3$ and $438.2 \rightarrow 357.1$, respectively. Collision energies were 
$24 \mathrm{eV}$ (OSIM) and $27 \mathrm{eV}$ (PAZO). Tube lens values were 96 (OSIM) and 120 (PAZO).

\section{6 | Method validation}

The validation was based on the most recent guideline 'bio-analytical method validation' by the European Medicines Agency (European Medicines Agency, 2011).

\subsection{1 | Selectivity and carryover}

Selectivity was evaluated by analyzing six different EDTA-plasma samples from patients who were not treated with OSIM. The largest peaks close to the retention times of OSIM and PAZO were manually integrated. These values were compared with the response of the lowest response in one of the five LLOQs in the same validation run. The response for OSIM should be $<20 \%$ of the LLOQ. For PAZO, the response should not exceed $5 \%$ of the peak area of the internal standard. Carryover was tested by injecting a blank plasma sample after an ULOQ sample. Analysis was carried out 5-fold. The limits for carryover are similar to the limits for selectivity $[<15 \%$ for OSIM $(<20 \%$ for LLOQ), and < 5\% for PAZO].

\subsubsection{Lower limit of quantification and linearity}

The mean plasma trough concentration in the population has been reported (166 ng/ml) (Verheijen et al., 2017) and no unexpected results were encountered while analyzing patients samples. The expected concentrations of patient samples in clinical practice is $\geq 40 \mathrm{ng} / \mathrm{ml}$, therefore the LLOQ was set at $25 \mathrm{ng} / \mathrm{ml}$. The upper limit of quantification was set at $500 \mathrm{ng} / \mathrm{ml}$, resulting in a calibration range from 25 to $500 \mathrm{ng} / \mathrm{ml}$. In other studies, wider concentration ranges were used (between 0.5 and $4000 \mathrm{ng} / \mathrm{ml}$ ) (Reis et al., 2018; Rood et al., 2016; Veerman et al., 2019; Zheng et al., 2018), but such a wide concentration range was considered unnecessary for this analytical method because the results in the planned follow-up study are expected to be within the range of 25-500 ng/ml. Three calibration curves were constructed $(y=a x+$ $b$, weighting $1 / x$ ) and back-calculated concentrations were not allowed to exceed $15 \%$ of the nominal value, except for the LLOQ, which was allowed to remain within $20 \%$ of the nominal value (Agency, 2011).

\subsection{3 | Precision and accuracy}

Precision and accuracy of the developed method were determined by analyzing five different QCs (LLOQ, $Q C_{\text {LOW }}, \mathrm{QC}_{\mathrm{MED}}, \mathrm{QC}_{\mathrm{HIGH}}$ and ULOQ) on three different days using freshly prepared calibration standards to construct the calibration curve. On each day, five replicates of each QC were analyzed. Precision and accuracy were not allowed to exceed $15 \%$ for all QCs, except for the LLOQ which was allowed to remain within 20\% (Agency, 2011).

\subsection{4 | Matrix effect}

Matrix effects were determined by calculating the ratio of the peak area after spiking the blank matrix with OSIM and PAZO and comparing this with OSIM and PAZO in the mobile phase (70\% A-30\% B). This was done for $\mathrm{QC}_{\mathrm{LOW}}$ and $\mathrm{QC}_{\mathrm{HIGH}}$.

\subsection{5 | Dilution integrity}

Usually, dilution integrity is tested by diluting plasma (c = $1.5 \times$ ULOQ) 4- and 2-fold (European Medicines Agency, 2011). However, during the development of this method, we found that the stability of OSIM at room temperature (RT) is shorter than $4 \mathrm{~h}$, as reported by Rood et al. (2016). The precise quantification of OSIM was therefore limited to the whole calibration range, which was sufficient for our planned study.

\subsection{6 | Stability}

Short- and long-term stabilities of OSIM were determined in human serum (additives-free) for $\mathrm{QC}_{\mathrm{LOW}}, \mathrm{QC}_{\mathrm{MED}}$ and $\mathrm{QC}_{\mathrm{HIGH}}$ at three different temperatures ( $\mathrm{RT}, 4^{\circ} \mathrm{C}$ and $-80^{\circ} \mathrm{C}$ ). For the stock solution of OSIM as well as for the working solution, the long-term stability was determined at $-80^{\circ} \mathrm{C}$. Accuracy was not allowed to exceed $15 \%$ of the nominal value. Twenty-four-hour stability was tested by reinjecting all QCs and calibration standards in the autosampler (maintained at $10^{\circ} \mathrm{C}$ ).

Short-term stability of OSIM at RT was evaluated in more detail. Human serum was spiked with OSIM (QC $\mathrm{L}_{\mathrm{LO}}$ and $\mathrm{QC}_{\mathrm{HIGH}}$ ) and immediately frozen afterwards. Samples were thawed on another day and stored at RT for $0,0.5,1,1.5,2,3,4,5$ and $6 \mathrm{~h}$ before sample preparation and analysis.

Short-term stability of OSIM at RT was also investigated in EDTA-plasma, heparinized plasma and whole blood, which was anticoagulated with EDTA. Additionally, the stability of OSIM was also evaluated with two patient samples. Stability was evaluated after 0, 2, 4,8 and $24 \mathrm{~h}$ of storage at RT. EDTA-plasma samples, heparinized plasma samples and whole blood samples were spiked with OSIM (QC $\mathrm{LOW}_{\text {LOW }} \mathrm{QC}_{\mathrm{HIGH}}$ ).

A study by Kallepalli et al. indicated that OSIM was more stable in an acidic environment (Kallepalli \& Annapurna, 2018). The effect of $\mathrm{pH}$ on the stability of OSIM in human serum was assessed by acidifying or alkalizing human serum with $0.1 \mathrm{ml}$ hydrochloric acid $(0.1 \mathrm{M})$ or $0.1 \mathrm{ml}$ sodium hydroxide $(0.1 \mathrm{M})$, respectively. Barring the buffering effect of serum, the $\mathrm{pH}$ of the samples would be $\sim 2$ and 12, respectively. Subsequently, the serum samples were spiked with OSIM 
( $\mathrm{QC}_{\text {LOW }}$ and $\mathrm{QC}_{\mathrm{HIGH}}$ ). OSIM concentration was determined after 0,2 and $4 \mathrm{~h}$ of storage at RT.

\section{3 | RESULTS AND DISCUSSION}

\section{1 | Method development}

Initially, the method described by Rood et al. was adopted, using a salting-out liquid-liquid extraction (Rood et al., 2016). After extraction and centrifugation the clear and colorless extract was transferred and tested for residual dissolved protein. The extract turned milky after adding methanol, indicating residual dissolved protein to be present. As continuous injection of dissolved protein on the chromatographic column would lead to amorphous peaks and a reduced lifespan of the column, simply adopting this method was not possible. Therefore, a new method for sample preparation was developed in which methanol was used for protein precipitation. This is largely comparable with the sample preparation described in other studies, which used acetonitrile for protein precipitation (Reis et al., 2018; Veerman et al., 2019; Zheng et al., 2018).

Preferably, labeled OSIM should have been used as internal standard. However, this was not commercially available at the time, and therefore PAZO has been used as internal standard. For OSIM and PAZO the most abundant fragments were chosen (OSIM $500.3 \rightarrow$ 72.3 and PAZO $438.2 \rightarrow 357.1$ ), which were similar to the transitions used in the study by Rood et al. (2016).

Several gradients were investigated but no gradient was found competent to co-elute OSIM and PAZO exactly simultaneously, thereby minimizing the risk of ion-suppression or -enhancement. OSIM and PAZO were slightly separated at every evaluated gradient, as shown in Figure 1. Additionally, calibration curves were created using three different plasma batches (data not shown). This was done prior to the start of the validation. The slope of the three calibration curves were compared and no differences were encountered regarding possible ion suppression or ion enhancement.

During method development carryover was observed with OSIM. A flush/needle-wash solution of water and methanol (50:50) was not sufficient to reduce the carryover to required levels. Carryover was significantly reduced by using a flush/needle-wash solution containing water, methanol, acetonitrile and isopropanol (25\% each). The optimization of the sample preparation was carried out by varying the volume of methanol. Dilution varied from 1:1 to 1:7 (sample/methanol). At every extract, additional methanol was added to visually check for residual protein (milky extract). Dilution 1:1 to 1:5 resulted in milky extracts (visually expected). Dilution 1:6 gave a clear extract. To ensure sufficient deproteinization a dilution of $\sim 1: 7.5$ was used at the start of the method validation of the method $(20 \mu \mathrm{l}$ sample $+150 \mu \mathrm{l}$ methanol).

As stability of OSIM at RT was considerably worse than described by Rood et al. (2016), sample preparation was performed on dry-ice to reduce degradation during sample preparation. It has been shown that OSIM is stable when stored on ice (Veerman et al., 2019).

\section{2 | Method validation}

\subsection{1 | Selectivity and carryover}

Six blank human plasma samples showed no interfering peaks. Blank OSIM responses were all <10\% (range 0.8-6.7\%). Blank IS responses were all $<0.1 \%$ (range $0.0-0.1 \%$ ). The carryover effect for OSIM did not exceed $20 \%$ of LLOQ (range 7.3-11.1\%), while the carryover effect for PAZO was $<0.2 \%$ of IS (range $=0.1-0.2 \%$ ).

\subsection{2 | Calibration and linearity}

The calibration curves were linear over the examined range $(25-500 \mathrm{ng} / \mathrm{ml})$. The coefficient of determination varied between 0.9964 and 0.9989 .

\subsection{3 | Precision and accuracy}

The results of the precision and accuracy of the analysis are shown in Table 1. The mean intra- and inter-day precisions of OSIM were 5.0 and $3.9 \%$. The mean intra- and inter-day accuracies were 91.2 and 94. $7 \%$. All precisions and accuracies met the pre-specified requirements (<15 or $<20 \%)$.

\subsection{4 | Matrix effect}

The matrix effect was evaluated using $\mathrm{QC}_{\mathrm{LO}}$ and $\mathrm{QC}_{\mathrm{HIGH}}$. The coefficient of variation was 12.8 and $12.2 \%$, respectively.

\subsection{5 | Stability}

\section{Short- and long-term stability}

The results of the short- and long-term stabilities of OSIM in human serum (additives-free) are shown in Table 2. Stability was tested using three different concentrations ( $\mathrm{QC}_{\mathrm{LOW}}, \mathrm{QC}_{\mathrm{MED}}$ and $\left.\mathrm{QC}_{\mathrm{HIGH}}\right)$. The concentration of OSIM in human serum declined rapidly when stored at RT. After $24 \mathrm{~h}$, the concentration of OSIM had decreased to $0.8 \%$ ( $\left.Q C_{\text {LOW }}\right), 1.9 \%\left(\mathrm{QC}_{\mathrm{MED}}\right)$ and $7.5 \%\left(\mathrm{QC}_{\mathrm{HIGH}}\right)$. When stored at $4{ }^{\circ} \mathrm{C}$, the decline in concentration was less considerable than at RT; however, after $24 \mathrm{~h}$ the concentrations of OSIM had fallen to $55.3 \%$ ( $\mathrm{QC}_{\mathrm{LOW}}$ ), 61.5\% ( $\left(\mathrm{QC}_{\mathrm{MED}}\right)$ and 63.3\% ( $\left(\mathrm{QC}_{\mathrm{HIGH}}\right)$. Because the concentrations after $24 \mathrm{~h}$ were far below the required norm, stability at those temperatures was not further evaluated. Nonetheless, OSIM proved to be stable when stored at $-80^{\circ} \mathrm{C}$, which was tested after 1,3 and 6 months (QC Low, 105.3, 109.2 and 93.5\%; QC MED $_{\text {L }} 102.2,109.3$ and 95.2\%; $\mathrm{QC}_{\mathrm{HIGH}}, 104.6,105.0$ and 95.9\%).

Short-term stability of OSIM in human serum at RT was investigated in more detail (Tables 3 and S1). The calculated concentrations were compared with the starting concentration at $T=0$. Similar to the 

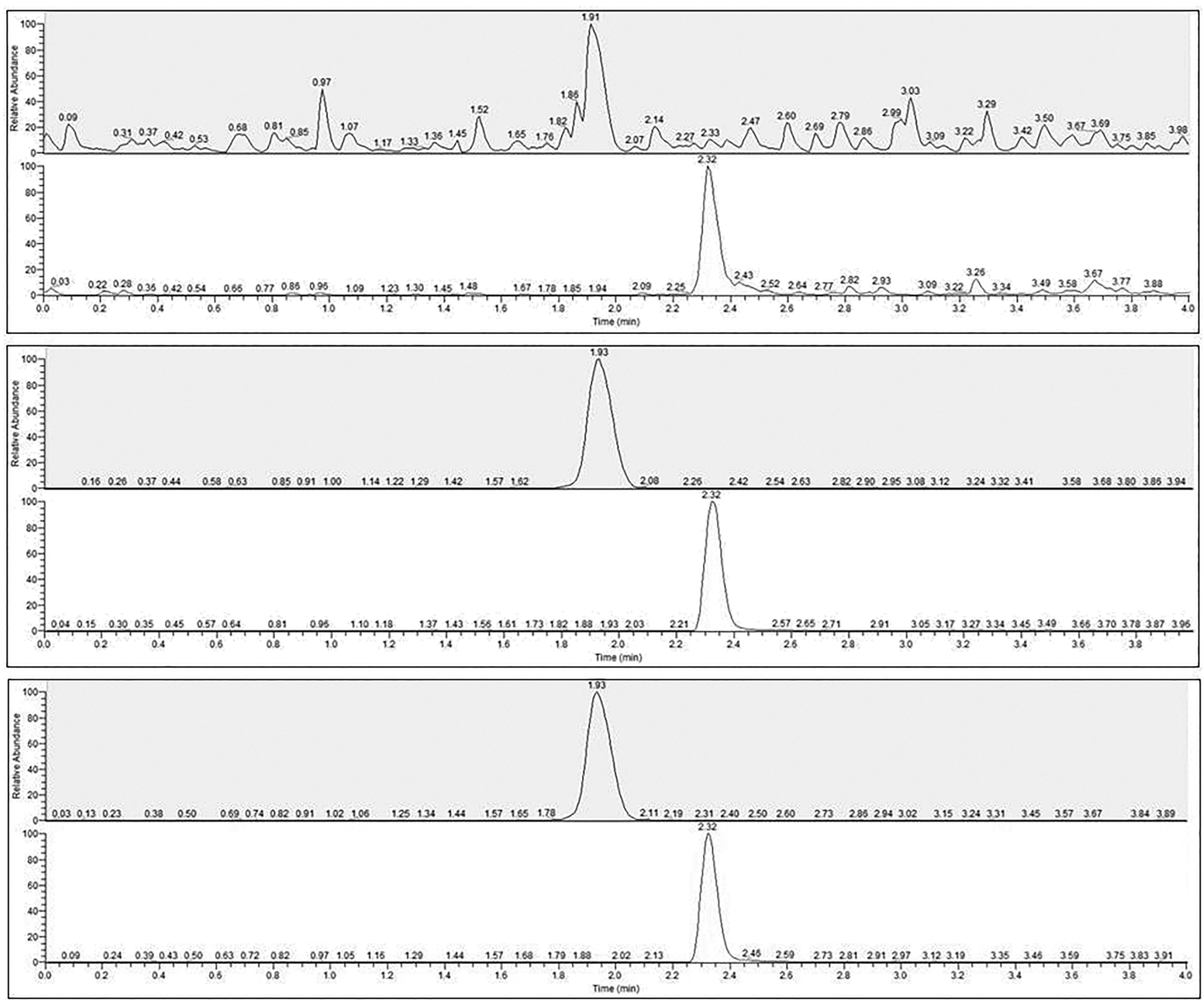

FIGURE 1 'Relative abundances of the chromatograms of osimertinib and pazopanib for a blank sample (upper), the LLOQ (middle) and a patient sample (lower). The maximum signal for osimertinib were 4.91E2 (blank sample), 1.04E5 (LLOQ) and 1.16E5 (patient sample).'

earlier results, the concentration of OSIM decreased drastically over time. After $4 \mathrm{~h}$ of storage at RT the concentration of OSIM had dropped to $18.6 \%\left(\mathrm{QC}_{\mathrm{LOW}}\right)$ and $54.1 \%\left(\mathrm{QC}_{\mathrm{HIGH}}\right)$, but the concentrations of OSIM in human serum declined below $85 \%$ of the original concentration after $0.5 \mathrm{~h}$ for $\mathrm{QC}_{\mathrm{LOW}}$ and after $1 \mathrm{~h}$ for $\mathrm{QC}_{\mathrm{HIGH}}$.

TAB LE 1 Intra- and inter-day accuracy and precision of osimertinib in spiked human serum samples

\begin{tabular}{|c|c|c|c|c|c|}
\hline $\begin{array}{l}\text { Nominal } \\
\text { concentration } \\
\text { (ng/L) }\end{array}$ & $\begin{array}{l}\text { Mean concentration } \\
(n=15)(\mathrm{ng} / \mathrm{ml})\end{array}$ & $\begin{array}{l}\text { Intra-day precision } \\
(n=5)(\%)\end{array}$ & $\begin{array}{l}\text { Inter-day precision } \\
(n=15)(\%)\end{array}$ & $\begin{array}{l}\text { Intra-day accuracy } \\
(n=5)(\%)\end{array}$ & $\begin{array}{l}\text { Inter-day accuracy } \\
(n=15)(\%)\end{array}$ \\
\hline LLOQ (25.0) & 24.9 & 8.0 & 4.7 & 98.1 & 99.5 \\
\hline $\mathrm{QC}_{\text {Low }}(75.0)$ & 65.9 & 3.9 & 2.0 & 85.9 & 87.9 \\
\hline $\mathrm{QC}_{\mathrm{MED}}(250.0)$ & 233.8 & 3.3 & 3.2 & 90.5 & 93.5 \\
\hline Mean & - & 5.0 & 3.9 & 91.2 & 94.7 \\
\hline
\end{tabular}

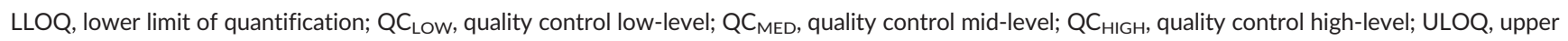
limit of quantification; $n=$ number of samples. 
TABLE 2 Stability of osimertinib in human serum at various storage conditions

\begin{tabular}{lccll}
$\begin{array}{l}\text { Temperature } \\
\left({ }^{\circ} \mathrm{C}\right)\end{array}$ & $\begin{array}{l}\text { Time } \\
\text { (days) }\end{array}$ & $\begin{array}{l}\text { Accuracy } \\
\mathrm{QC}_{\text {Low }}(\%)\end{array}$ & $\begin{array}{l}\text { Accuracy } \\
\mathrm{QC}_{\text {MED }}(\%)\end{array}$ & $\begin{array}{l}\text { Accuracy } \\
\mathrm{QC}_{\text {HIGH }}(\%)\end{array}$ \\
\hline-80 & 30 & 105.3 & 102.2 & 104.6 \\
-80 & 90 & 109.2 & 109.3 & 105.0 \\
-80 & 180 & 93.5 & 95.2 & 95.9 \\
\hline $2-8$ & 1 & 55.3 & 61.5 & 63.3 \\
\hline $15-25(\mathrm{RT})$ & 1 & 0.8 & 1.9 & 7.5 \\
\hline
\end{tabular}

$\mathrm{RT}$, room temperature; $\mathrm{QC}_{\mathrm{LOW}}$, quality control low-level; $\mathrm{QC}_{\mathrm{MED}}$, quality control mid-level; $\mathrm{QC}_{\mathrm{HIGH}}$, quality control high-level. Results are mean concentration compared with nominal value. All concentrations were analyzed in duplicate.

The results of OSIM stability in two patient samples (heparinized plasma) are shown in Table 3 and Figure S1. After $4 \mathrm{~h}$ of storage at RT the concentration of OSIM had fallen to 84.4 and $84.5 \%$, respectively. The degradation of OSIM seen in patient plasma was considerably lower than the degradation observed in human serum (QC $C_{\text {LOW }}, 18.6 \%$ and $\left.\mathrm{QC}_{\mathrm{HIGH}}, 54.1 \%\right)$, while the concentrations of the two patients samples $(102.58$ and $303.60 \mathrm{ng} / \mathrm{ml})$ were in the same range as the concentration of the quality controls. The type of anticoagulation could possibly influence OSIM stability, as shown in Table 3 and Figure S1. After $4 \mathrm{~h}$ of storage at RT the concentration of OSIM in EDTA-plasma had decreased to $91.9 \%\left(\mathrm{QC}_{\mathrm{LOW}}\right)$ and $86.4 \%\left(\mathrm{QC}_{\mathrm{HIGH}}\right)$ and to $60.1 \%$ (QC $\mathrm{LOW}_{\mathrm{LOW}}$ ) and $64.4 \%\left(\mathrm{QC}_{\mathrm{HIGH}}\right)$ after 24 hours. In heparinized plasma the decrease was noticeably larger, as the concentration declined to $67.1 \%\left(\mathrm{QC}_{\mathrm{LOW}}\right)$ and $72.1 \%\left(\mathrm{QC}_{\mathrm{HIGH}}\right)$ after $4 \mathrm{~h}$ and to $2.0 \%$ (QC $\mathrm{LOW}_{\text {LOW }}$ ) and $2.9 \%\left(\mathrm{QC}_{\mathrm{HIGH}}\right)$.

The stability of OSIM in whole blood at room temperature is shown in Table 3. After $4 \mathrm{~h}$ of storage at room temperature the concentration of OSIM had decreased to $88.4 \%$ ( $\left.\mathrm{QC}_{\mathrm{LOW}}\right)$ and 96.3\% (QC $\mathrm{QHIGH}_{\mathrm{HI}}$. After $24 \mathrm{~h}$ at RT the concentration fell to $54.7 \%$ ( $Q C_{\text {LOW }}$ ) and $93.6 \%\left(\mathrm{QC}_{\mathrm{HIGH}}\right)$. Upon storage at $4{ }^{\circ} \mathrm{C}$ the concentration of OSIM had decreased to $79.2 \%$ (QC LOW $_{\text {) }}$ and $96.6 \%$ $\left(\mathrm{QC}_{\mathrm{HIGH}}\right)$ after $4 \mathrm{~h}$ and to $53.6 \%\left(\mathrm{QC}_{\mathrm{LOW}}\right)$ and $91.0 \%$ (QC $\left.\mathrm{LOW}_{\mathrm{LOW}}\right)$ after $24 \mathrm{~h}$ (results not shown).

The effect of $\mathrm{pH}$ on OSIM stability is shown in Table 3. OSIM was more stable in acidified serum as compared with alkalized serum. After $4 \mathrm{~h}$ of storage at RT the concentration of OSIM decreased to 79.5\% (QC $\mathrm{CLW}_{\mathrm{LOW}}$ ) and 91.1\% ( $\left.\mathrm{QC}_{\mathrm{HIGH}}\right)$ in an acidic environment, while the concentration of OSIM fell to 3.2\% (QC $\mathrm{LOW}_{\mathrm{LOW}}$ ) and 14.9\% (QC $\left.\mathrm{CHIG}_{\mathrm{HI}}\right)$ when human serum was alkalized. These results match the results presented by Kallepalli \& Annapurna (2018), which showed that OSIM was relatively stable in an acidic environment but degraded rapidly in an alkaline environment.

Freeze-thaw stability of OSIM was performed in other studies and all reported sufficient accuracy after three freeze-thaw cycles (Reis et al., 2018; Rood et al., 2016; Veerman et al., 2019; Zheng et al., 2018). Owing to the rapid decline of OSIM at RT encountered in this study, it was decided not to evaluate the freeze-thaw stability of OSIM because storage at RT would inevitably lead to lower OSIMconcentrations.

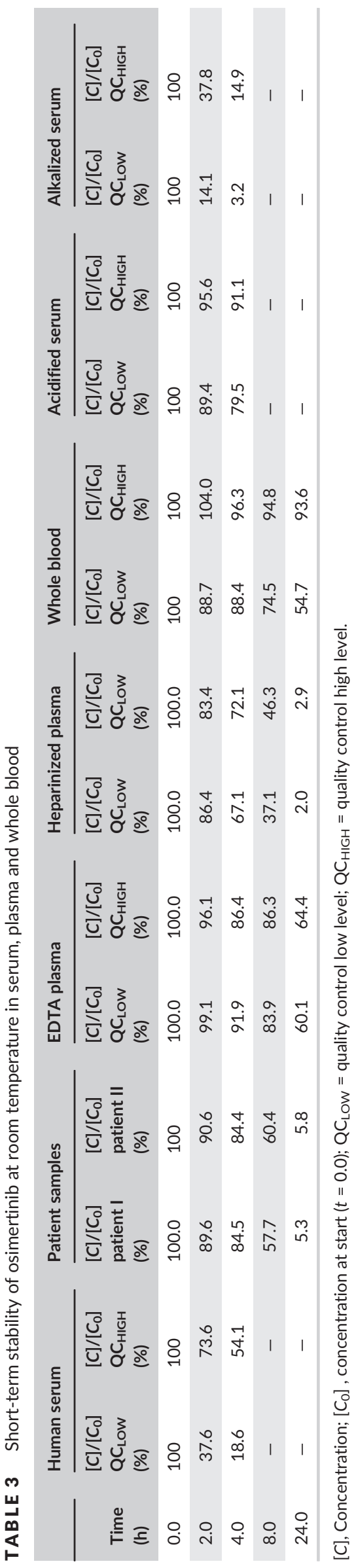


A limitation of this validation was that during stability-testing the concentration of OSIM repeatedly declined $<25 \mathrm{ng} / \mathrm{ml}$. As the calibration range was set from 25 to $500 \mathrm{ng} / \mathrm{ml}$ some concentrations could not be calculated completely accurately. As this was solely seen during stability tests, this was not considered serious. However, this uncertainty should be kept in mind while evaluating the stability results of OSIM at concentrations $<25 \mathrm{ng} / \mathrm{ml}$.

\section{Stock stability}

OSIM proved stable in DMSO when stored at $-80^{\circ} \mathrm{C}$. After 3 weeks and 3 and 6 months all accuracies were between 95 and 105\%. OSIM proved unstable when dissolved in methanol. After 3 weeks the concentration had dropped to $68.6 \%$ and was therefore not further evaluated. Results are shown in Table S2 in the Supporting Information.

The long-term stability of PAZO was examined previously, and PAZO proved to be stable in plasma at different temperatures (Minocha, Khurana, \& Mitra, 2012; van Erp et al., 2013; Verheijen et al., 2018). PAZO was stable for up to 9 months at $20^{\circ} \mathrm{C}$ and up to 3 months at RT and at $2-8^{\circ} \mathrm{C}$. Therefore, PAZO was considered to be stable and no additional analyses were performed.

\subsubsection{Clinical applicability}

This assay was developed to support clinical studies as well as individual patient care in a real-world clinical setting. We analyzed multiple patient samples of patients treated with OSIM. All measured concentrations were between 51.8 and $303.6 \mathrm{ng} / \mathrm{ml}$ and therefore within the pre-specified range of $25-500 \mathrm{ng} / \mathrm{ml}$ used for this analytical method. Incurred sample reanalysis was performed for one sample, which was reanalyzed in a different run after storage at $-80^{\circ} \mathrm{C}$ for 6 weeks. The OSIM concentrations were similar in both measurements $(102.6 \mathrm{ng} / \mathrm{ml}$ and $105.0 \mathrm{ng} / \mathrm{ml})$, indicating good reproducibility of the method. Incurred sample reanalysis assessment will be performed in additional patient samples as part of an on-going clinical trial (NCT03858491).

\section{3 $\quad$ Comparison with previous studies}

Other analytical methods for OSIM have been published previously. While some have mainly focused on OSIM alone or in combination with its metabolites (Irie et al., 2019; Mitchell et al., 2019; Rood et al., 2016; Zheng et al., 2018), others developed an analytical method for multiple TKIs (Janssen et al., 2019; Reis et al., 2018; Veerman et al., 2019). As the active metabolites of OSIM account for $~ 10 \%$ of the total OSIM AUC (Planchard et al., 2016; Vishwanathan et al., 2019), they could contribute to the efficacy and toxicity of osimertinib, with AZ5104 being the most likely option owing to the increased potency seen in in-vitro studies (Cross et al., 2014). Although AZ5104 was not included in our method, AZ5104 exposure could be estimated based on the osimertinib exposure, as the intra- and inter-patient variability in the osimertinib to AZ5104 ratio is small. Furthermore, since elimination rates for OSIM and AZ5104 are similar, the parent to metabolite ratio remains consistent over time within each dosing interval (Vishwanathan et al., 2019).

In our method, HPLC was used for separation, whereas other studies mainly used ultra-high-performance liquid chromatography (UPLC) for separation (Janssen et al., 2019; Mitchell et al., 2019; Rood et al., 2016; Veerman et al., 2019; Zheng et al., 2018). As UPLC may not be available in all laboratories, the use of HPLC could enable more laboratories to implement the quantification of OSIM. Although HPLC methods usually have longer run times (Reis et al., 2018), we achieved a run time of $3.8 \mathrm{~min}$, which is comparable with the run time of 2-5 min reported for the UPLC methods (Janssen et al., 2019; Mitchell et al., 2019; Rood et al., 2016; Veerman et al., 2019; Zheng et al., 2018). Furthermore, our sample preparation was largely comparable with the methods used in UPLC methods, but considerably shorter than the only other reported HPLC method (Reis et al., 2018). Therefore this analytical method could serve as an easy, quick, and relatively cheap option in laboratories in which UPLC systems are not available.

Contrasting results have been reported regarding the short-term stability of OSIM, especially at RT. While multiple studies described good stability of OSIM at RT for at least $6 \mathrm{~h}$ (Mitchell et al., 2019; Reis et al., 2018;Rood et al., 2016 ; Zheng et al., 2018), others reported more limited stability, namely 3-4 h (Janssen et al., 2019; Veerman et al., 2019). However, differences in OSIM concentrations and type of plasma complicate adequate comparison of the results of these studies. Therefore, we decided to assess the short-term stability of OSIM in serum, plasma (EDTA and heparinized) and whole blood, using invariable concentrations of OSIM and fixed laboratory conditions.

The short-term stability of OSIM in heparinized plasma in our study was $\sim 2 \mathrm{~h}$, which was considerably shorter than the previously described 6 h (Rood et al., 2016; Zheng et al., 2018). Our results were comparable with the results reported by Veerman et al., who described short-term stability of OSIM in heparinized plasma for at least $3 \mathrm{~h}$ and a recovery after $24 \mathrm{~h}$ of $<20 \%$ (Veerman et al., 2019). According to previous studies, OSIM was stable for at least 4-6 h in EDTA plasma at RT (Janssen et al., 2019; Mitchell et al., 2019). Similarly, we found that OSIM was stable in EDTA-plasma for at least $4 \mathrm{~h}$ at RT. As indicated by a 60-65\% recovery of OSIM in EDTA-plasma after $24 \mathrm{~h}$ at RT, the rate of OSIM degradation was considerably less than in heparinized plasma.

In whole blood, OSIM was reported to be stable for at least $5 \mathrm{~h}$ at $\mathrm{RT}$, and for $1 \mathrm{~h}$ at $37^{\circ} \mathrm{C}$ (Veerman et al., 2019). Mitchell et al. reported OSIM to be stable for at least $2 \mathrm{~h}$ at RT. Prior to storage at RT, the blood samples were heated to $37^{\circ} \mathrm{C}$ to mimic the situation in clinical practice (Mitchell et al., 2019). In our study, OSIM was stable for at least $4 \mathrm{~h}$ at $\mathrm{RT}$, which is comparable with the results reported by Veerman et al.

To the best of our knowledge the effect of $\mathrm{pH}$ on the shortterm stability was not previously evaluated. We showed that acidification of serum samples has a positive effect on the short-term 
stability of OSIM compared with alkalinization or no $\mathrm{pH}$ modification.

The long-term stability of OSIM was evaluated under freezing conditions $\left(-20,-30,-70\right.$ and $\left.-80^{\circ} \mathrm{C}\right)$ and similar results were found in all studies. OSIM proved to be stable in freezing conditions for at least 1 month, but longer stability was reported (up to 9 months) in multiple studies (Janssen et al., 2019; Mitchell et al., 2019; Reis et al., 2018; Rood et al., 2016; Veerman et al., 2019; Zheng et al., 2018).

\section{4 | CONCLUSION}

An HPLC-MS/MS method to quantify OSIM was successfully developed and validated with a similar run-time as previously published UPLC-MS/MS methods. Accuracy, precision, carryover and matrix effect were in accordance with the European Medicines Agency guidelines. The short-term stability of OSIM in human serum, heparinized and EDTA plasma is limited at RT. Although the degradation rate of OSIM is lower in an acidic environment and EDTA-plasma, storage at room temperature should be minimized in order to maintain reliable analysis. Preferably, blood samples should be transported on ice upon collection and stored in the freezer as quickly as possible. Sample workup should ideally be performed on dry-ice. EDTA-containing tubes and plasma sample acidification may be used. However, in order to implement such an approach, further research to develop specific instructions and subsequently validate such a method would be necessary. The clinical applicability of our method was demonstrated by quantitative analysis of blood samples from lung cancer patients treated with OSIM. This bio-analytical assay will be extensively used as part of an on-going clinical trial (NCT0385491) and may be used as part of routine care in the future.

\section{CONFLICT OF INTEREST}

Ard van Veelen, no relationships to disclose. Robin van Geel, no relationship to disclose. Yvo de Beer, no relationships to disclose. Anne-Marie Dingemans, none related to current manuscript; outside of current manuscript, advisory board BMS, MSD, Roche, Eli Lilly, Takeda, Pfizer, Boehringer Ingelheim (all institutions); research grant, BMS (institution). Leo Stolk, no relationships to disclose. Rob ter Heine, no relationships to disclose. Frank de Vries, supervises two PhD students who are employed by F. Hoffman La Roche Ltd (Basel Switzerland and Welwyn Garden City UK); the topics of one of these PhD students is related to lung cancer, the topic of the other PhD student is not related to the current work; FV has not received any fees or reimbursements for this. Sander Croes, supervises one PhD student who is employed by F. Hoffman La Roche Ltd (Welwyn Garden City UK); The topics of this PhD student are related to lung cancer; SC has not received any fees or reimbursement for this work.

\section{FUNDING SOURCES}

This assay development was part of a project focused on osimertinib. This project was funded by the Netherlands Organization for
Health Research and Development (ZonMW), grant number 80-84800-98-17042.

\section{ORCID}

Ard van Veelen (D) https://orcid.org/0000-0002-4869-5791

\section{REFERENCES}

European Medicines Agency. 2011. Guideline on bioanalytical method validation. https://www.ema.europa.eu/en/documents/scientificguideline/guideline-bioanalytical-method-validation_en.pdf

Brown, K., Comisar, C., Witjes, H., Maringwa, J., de Greef, R., Vishwanathan, K., ... Cox, E. (2017). Population pharmacokinetics and exposure-response of osimertinib in patients with non-small cell lung cancer. British Journal of Clinical Pharmacology, 83, 1216-1226. https://doi.org/10.1111/bcp.13223

Cross, D. A., Ashton, S. E., Ghiorghiu, S., Eberlein, C., Nebhan, C. A., Spitzler, P. J., ... Pao, W. (2014). AZD9291, an irreversible EGFR TKI, overcomes T790M-mediated resistance to EGFR inhibitors in lung cancer. Cancer Discovery, 4, 1046-1061. https://doi.org/10.1158/ 2159-8290.CD-14-0337

Ferlay, J., Soerjomataram, I., Dikshit, R., Eser, S., Mathers, C., Rebelo, M., ... Bray, F. (2015). Cancer incidence and mortality worldwide: sources, methods and major patterns in GLOBOCAN 2012. International Journal of Cancer, 136, E359-E386. https://doi.org/10.1002/ijc.29210

Herbst, R. S., Heymach, J. V., \& Lippman, S. M. (2008). Lung cancer. The New England Journal of Medicine, 359, 1367-1380. https://doi.org/10. 1056/NEJMra0802714

Irie, K., Nanjo, S., Hata, A., Yamasaki, Y., Okada, Y., Katakami, N., \& Fukushima, S. (2019). Development of an LC-MS/MS-based method for quantitation of osimertinib in human plasma and cerebrospinal fluid. Bioanalysis, 11, 847-854.

Janssen, J. M., de Vries, N., Venekamp, N., Rosing, H., Huitema, A. D. R., \& Beijnen, J. H. (2019). Development and validation of a liquid chromatography-tandem mass spectrometry assay for nine oral anticancer drugs in human plasma. Journal of Pharmaceutical and Biomedical Analysis, 174, 561-566.

Kallepalli, P., \& Annapurna, M. M. (2018). A new validated stability indicating UPLC method for the quantitative analysis of osimertinib tablets. Acta Scientific Pharmaceutical Sciences, 2, 2-6.

Minocha, M., Khurana, V., \& Mitra, A. K. (2012). Determination of pazopanib (GW-786034) in mouse plasma and brain tissue by liquid chromatography-tandem mass spectrometry (LC/MS-MS). Journal of Chromatography B, Analytical Technologies in the Biomedical and Life Sciences, 901, 85-92. https://doi.org/10.1016/j.jchromb.2012. 06.004

Mitchell, R., Bailey, C., Ewles, M., Swan, G., \& Turpin, P. (2019). Determination of osimertinib in human plasma, urine and cerebrospinal fluid. Bioanalysis, 11, 987-1001. https://doi.org/10.4155/bio-2018-0262

Mok, T. S., Wu, Y. L., Ahn, M. J., Garassino, M. C., Kim, H. R., Ramalingam, S. S., ... Aura Investigators (2017). Osimertinib or platinum-pemetrexed in EGFR T790M-positive lung cancer. The New England Journal of Medicine, 376, 629-640.

Planchard, D., Brown, K. H., Kim, D. W., Kim, S. W., Ohe, Y., Felip, E., ... Dickinson, P. A. (2016). Osimertinib Western and Asian clinical pharmacokinetics in patients and healthy volunteers: Implications for formulation, dose, and dosing frequency in pivotal clinical studies. Cancer Chemotherapy and Pharmacology, 77, 767-776. https://doi.org/10. 1007/s00280-016-2992-z

Reis, R., Labat, L., Allard, M., Boudou-Rouquette, P., Chapron, J., Bellesoeur, A., ... Blanchet, B. (2018). Liquid chromatography-tandem mass spectrometric assay for therapeutic drug monitoring of the EGFR inhibitors afatinib, erlotinib and osimertinib, the ALK inhibitor crizotinib and the VEGFR inhibitor nintedanib in human plasma from 
non-small cell lung cancer patients. Journal of Pharmaceutical and Biomedical Analysis, 158, 174-183. https://doi.org/10.1016/j.jpba. 2018.05.052

Rood, J. J. M., van Bussel, M. T. J., Schellens, J. H. M., Beijnen, J. H., \& Sparidans, R. W. (2016). Liquid chromatography-tandem mass spectrometric assay for the T790M mutant EGFR inhibitor osimertinib (AZD9291) in human plasma. Journal of Chromatography. B, Analytical Technologies in the Biomedical and Life Sciences, 1031, 80-85. https:// doi.org/10.1016/j.jchromb.2016.07.037

Soria, J. C., Ohe, Y., Vansteenkiste, J., Reungwetwattana, T., Chewaskulyong, B., Lee, K. H., ... Flaura Investigators (2018). Osimertinib in untreated EGFR-mutated advanced non-small-cell lung cancer. The New England Journal of Medicine, 378, 113-125.

van Erp, N. P., de Wit, D., Guchelaar, H. J., Gelderblom, H., Hessing, T. J., \& Hartigh, J. (2013). A validated assay for the simultaneous quantification of six tyrosine kinase inhibitors and two active metabolites in human serum using liquid chromatography coupled with tandem mass spectrometry. Journal of Chromatography B, Analytical Technologies in the Biomedical and Life Sciences, 937, 33-43.

Veerman, G. D. M., Lam, M. H., Mathijssen, R. H. J., Koolen, S. L. W., \& de Bruijn, P. (2019). Quantification of afatinib, alectinib, crizotinib and osimertinib in human plasma by liquid chromatography/triplequadrupole mass spectrometry; focusing on the stability of osimertinib. Journal of Chromatography B, Analytical Technologies in the Biomedical and Life Sciences, 1113, 37-44. https://doi.org/10.1016/j. jchromb.2019.03.011

Verheijen, R. B., Thijssen, B., Rosing, H., Schellens, J. H. M., Nan, L., Venekamp, N., ... Huitema, A. D. R. (2018). Fast and straightforward method for the quantification of pazopanib in human plasma using LC-MS/MS. Therapeutic Drug Monitoring, 40, 230-236. https://doi. org/10.1097/FTD.0000000000000479
Verheijen, R. B., Yu, H., Schellens, J. H. M., Beijnen, J. H., Steeghs, N., \& Huitema, A. D. R. (2017). Practical recommendations for therapeutic drug monitoring of kinase inhibitors in oncology. Clinical Pharmacology and Therapeutics, 102, 765-776.

Vishwanathan, K., So, K., Thomas, K., Bramley, A., English, S., \& Collier, J. (2019). Absolute bioavailability of osimertinib in healthy adults. Clinical Pharmacology in Drug Development, 8, 198-207. https://doi.org/10. 1002/cpdd.467

Zhao, H., Cao, J., Chang, J., Zhang, Z., Yang, L., Wang, J., ... Zhang, L. (2018). Pharmacokinetics of osimertinib in chinese patients with advanced NSCLC: A phase 1 study. Journal of Clinical Pharmacology, 58, 504-513. https://doi.org/10.1002/jcph.1042

Zheng, X., Wang, W., Zhang, Y., Ma, Y., Zhao, H., Hu, P., \& Jiang, J. (2018). Development and validation of a UPLC-MS/MS method for quantification of osimertinib (AZD9291) and its metabolite AZ5104 in human plasma. Biomedical Chromatography, 32, e4365.

\section{SUPPORTING INFORMATION}

Additional supporting information may be found online in the Supporting Information section at the end of this article.

How to cite this article: van Veelen A, van Geel R, de Beer Y, et al. Validation of an analytical method using HPLC-MS/MS to quantify osimertinib in human plasma and supplementary stability results. Biomedical Chromatography. 2020;34:e4771. https://doi.org/10.1002/bmc.4771 